\title{
PROBOSTWO SZPITALNE PW. ŚW. HIERONIMA W KOBRYNIU W ŚWIETLE PROTOKOLU WIZYTACYJNEGO Z 1799 ROKU
}

\begin{abstract}
Streszczenie
W artykule zaprezentowano dzieje prepozytury szpitalnej pw. św. Hieronima w Kobryniu, jej stan i funkcjonowanie u schyłku XVIII wieku. Tekst został oparty na protokole z wizytacji generalnej przeprowadzonej w 1799 r. przez biskupa wileńskiego Jana Nepomucena (Korwina) Kossakowskiego w dekanatach kobryńskim i prużańskim. Dokument przechowywany jest w Litewskim Państwowym Archiwum Historycznym w Wilnie (Lietuvos Vlastybès Istorijos Archyvas) (LVIA) pod sygnaturą f. 694, ap. 1, b. 3570.

Słowa kluczowe: biskup Jan Nepomucen (Korwin) Kossakowski; dekanat kobryński; diecezja wileńska; Kobryń; prepozytura szpitalna; probostwo szpitalne; wizytacja generalna
\end{abstract}

$* * * * *$

Miasto Kobryń położone przy ujściu rzeki Kobrynki do Muchawca należy do najstarszych osad na dawnych Kresach Wschodnich Rzeczypospolitej. Przed rozbiorami wchodziło w skład powiatu brzeskiego, położonego w granicach województwa brzesko-litewskiego. Zaliczało się do znaczących ośrodków ekonomii brzesko-kobryńskiej należącej wówczas do dóbr stołowych królewskich w granicach Wielkiego Księstwa Litewskiego. Odgrywało ważną rolę gospodarczą, przemysłową i kulturalną. Okres największego rozwoju miasto przeżywało w XVI wieku, zwłaszcza po 1549 r., kiedy wraz z całym księstwem kobryńskim objęła

* Marek Hałaburda - dr hab. historii, adiunkt; Wydział Historii i Dziedzictwa Kulturowego; Uniwersytet Papieski Jana Pawła II w Krakowie

e-mail: marek.halaburda@upjp2.edu.pl

https://orcid.org/0000-0002-3801-9378 
w posiadanie królowa Bona ${ }^{1}$. Po rozbiorach Kobryń w randze siedziby powiatu został włączony do guberni grodzieńskiej (do $1801 \mathrm{r}$. nazywanej słonimską)².

Już na początku XV stulecia w mieście znajdowały się dwie świątynie rzymskokatolickie. Pierwszą z nich był kościół parafialny pw. Wniebowzięcia Najświętszej Maryi Panny (fara) ufundowany na początku XVI wieku przez Annę Kobryńską-Kostewiczową ${ }^{3}$. Druga to, wzniesiony mniej więcej w tym samym czasie, kościół prepozyturalny pw. św. Hieronima wraz ze szpitalem dla ubogich, notowany w źródłach i literaturze przedmiotu najczęściej jako probostwo szpitalne ${ }^{4}$. To właśnie tej świątyni poświęcony został niniejszy tekst. Drewniany kościół św. Hieronima wraz zabudowaniami szpitalnymi opisany w czasie wizytacji u schyłku XVIII wieku został wzniesiony na miejscu przynajmniej kilku wcześniejszych świątyń, również wybudowanych z drewna. Fundacja została odnowiona i uposażona w 1624 r. przez Hieronima (Jarosza) Wołłowicza, starostę generalnego żmudzkiego. Przeznaczył on wówczas na utrzymanie księdza i opiekę nad biednymi przebywającymi w szpitalu procent roczny od sumy 300 florenów polskich oraz 60 wozów opału. Odpowiedni zapis potwierdzono na zamku kobryńskim w dniu 16 września tegoż roku. Fundacja otrzymała zatwierdzenie królowej Konstancji, w Warszawie w dniu 19 marca 1625 r., oraz niespełna miesiąc później jej męża króla Zygmunta III Wazy, również w Warszawie (10 kwietnia 1625 r.) $)^{5}$. Mimo dużego znaczenia w dziejach Kobrynia, a także w historii instytucji charytatywnych w okresie staropolskim, probostwo szpitalne w Kobryniu nie doczekało się do tej pory odrębnego opracowania zarówno w historiografii białoruskiej, jak i polskiej. Szczątkowe dane na temat miasta, jego rozwoju architektonicznego oraz materialnej kultury Kościoła w końcu XVIII wieku można odnaleźć w leksykonach poświęconych zabytkom architektury oraz religii i kościołom na Białorusi ${ }^{6}$. Brak informacji o kobryńskim probostwie szpitalnym w Materiałach do dziejów

${ }^{1}$ Stownik geograficzny Królestwa Polskiego i Litwy i innych krajów stowiańskich, red. F. Sulimierski, t. 4, Warszawa 1883, s. 205-206; M. Marczak, Przewodnik po Polesiu, Brześć nad Bugiem 1935, s. 67; W. Filipczak, Ekonomie litewskie w polityce sejmikowej Stanisława Augusta po upadku Antoniego Tyzenhauza (1780-1783), „Przegląd Nauk Historycznych”, 5 (2006) nr 1 (9), s. 237; Л. Казлоў Кобрынская эканомія, ў: Вялікае Княства Літоўскае. Энцыкклапедыя у 2-х тамах, рд. Г.П. Пашкоў, т. 2, Мінск 2007, с. 117.

${ }^{2}$ Вялікі гістарычны атлас Беларусі у 4-х тамах, рд. Г.І. Кузняцоў, т. 3, Мінск 2016, с. 21, 30.

${ }_{3}^{3}$ Spis kościołów i duchowieństwa diecezji pińskiej w R.P. 1939, Pińsk 1939, s. 97.

${ }^{4}$ Biskupstwo Wileńskie: od jego założenia do dni obecnych, zawierające dzieje i prace biskupów i duchowieństwa diecezji wileńskiej, oraz wykaz kościołów, klasztorów, szkót i zakładów dobroczynnych i społecznych, oprac. J. Kurczewski, Wilno 1912, s. 235-236; S. Litak, Atlas Kościoła łacińskiego w Rzeczypospolitej Obojga Narodów w XVIII wieku, Lublin 2006, s. 344.

${ }^{5}$ Archiwum Diecezjalne w Siedlcach (dalej: ADS), sygn. D 155, k. 421.

${ }^{6}$ А.М. Кулагін, Каталіикія храмы Беларусі, Мінск 2008, s. 182-183; Рэлігія і Церква на Беларусі. Эниыкллапедычны даведнік, рэд. Г.П. Пашкоў, Мінск 2001, с. 163-164; Свод памятников истории и культуры Белоруссии. Брестская область, рэд. С.В. Марцелев, Минск 1990, 243-252; В.А. Чантурия, Архитектурные памятники Белоруссии, Минск 1982, с. 37-40. 
sztuki sakralnej na ziemiach wschodnich dawnej Rzeczypospolitej ${ }^{7}$. W ostatnim czasie w obiegu naukowym pojawiły się przynajmniej dwie publikacje poruszające problematykę kościołów Kobrynia napisane przez Adama Bobryka i Rafała Dmowskiego oraz ks. Waldemara W. Żurka SDB. W pierwszym i drugim tekście zawarto jedynie krótkie wzmianki o kościele św. Hieronima. Tak samo autorzy obydwu tekstów przywołują niestety błędną datę budowy świątyni, przesuwając czas jej zakończenia o blisko 300 lat ${ }^{8}$. Przedstawiona powyżej luka w stanie badań oraz powielana $\mathrm{w}$ literaturze przedmiotu nieprawdziwa data powstania szpitalnej świątyni wydają się wystarczającymi argumentami do podjęcia niniejszego zagadnienia.

Sprzyjają temu zachowane źródła historyczne. O ile brak dokumentów fundacyjnych uniemożliwia ustalenie precyzyjnej daty powstania fundacji i nazwisk jej fundatora lub fundatorów, to dla lat późniejszych istnieje bardziej obszerny materiał w postaci wizytacji biskupich. W przypadku probostwa szpitalnego w Kobryniu dostępne są tego rodzaju dokumenty od pierwszej połowy XVIII wieku. $\mathrm{W}$ analizach skoncentrowano się na protokole mało znanym, rzadko wykorzystywanym przez badaczy i równocześnie bardzo ważnym z punktu widzenia poznawczego. Chodzi o wizytację generalną kościołów w dekanacie kobryńskim i prużańskim z 1799 r. przedstawiającą stan probostwa szpitalnego na dwa lata przed pożarem, który zniszczył kościół wraz z całym wyposażeniem.

Wspomnianą wizytację kanoniczną pod koniec XVIII wieku przeprowadził osobiście biskup wileński Jan Nepomucen Kossakowski, w niespełna rok po swoim ingresie do katedry wileńskiej. Nowy ordynariusz chcąc poznać stan kościo-

${ }^{7}$ Zob. Materiaty do dziejów sztuki sakralnej na ziemiach wschodnich dawnej Rzeczypospolitej, cz. 5: Kościoły i klasztory rzymskokatolickie dawnego województwa brzeskolitewskiego, t. 1-4, red. J.K. Ostrowski, Kraków 2013-2019.

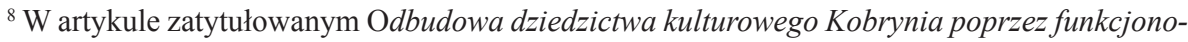
wanie parafii katolickiej autorzy A. Bobryk i R. Dmowski, powołując się na folder wydany przez Generalną Dyrekcję „Energopolu” poświęconą Kościołowi Wniebowzięcia NMP w Kobryniu (Warszawie 1990 r.), powielają nieprawdziwą informację o wybudowaniu kościoła szpitalnego w $1812 \mathrm{r}$. Zob. A. Bobryk, R. Dmowski, Odbudowa dziedzictwa kulturowego Kobrynia poprzez funkcjonowanie parafii katolickiej, w: Blisko, a tak daleko: Polacy w obwodzie brzeskim na Białorusi, red. A. Bobryk, Siedlce 2004, s. 195. Taką samą błędną datę wybudowania kościoła szpitalnego pw. św. Hieronima przywołuje ks. Waldemar W. Żurek SDB we wstępie do edycji źródłowej inwentarza kościoła parafialnego w Kobryniu z 1933 r. Zob. W.W. Żurek, Inwentarz rzymskokatolickiego kościoła parafialnego w Kobryniu z 21 sierpnia 1933 roku, „Archiwa, Biblioteki i Muzea Kościelne”, 109 (2018) s. 400. Tymczasem w 1801 r. kościół, który ufundowano już na początku XVI wieku, zniszczył pożar i nigdy nie został już odbudowany. Ponad wszelką wątpliwość potwierdzają to nie tylko dostępne źródła, ale również ustalenia wybitnego badacza dziejów diecezji wileńskiej ks. Jana Kurczewskiego. W monografii poświęconej temuż biskupstwu, pisząc o kościele św. Hieronima, zanotował: ,(...) był już na początku XVI w., spalił się w 1801 r. ze wszystkimi aparatami i sprzętami; potem nie było za co odbudować", Biskupstwo wileńskie, s. 235-236.

${ }^{9}$ Kossakowski Jan Nepomucen (Korwin) (1755-1808) h. Ślepowron - kształcił się w konwikcie pijarów w Warszawie (1755-1776) i seminarium misjonarzy przy kościele św. Krzyża w Warszawie (1776-1779); dalszą naukę kontynuował w Rzymie na Sapienzy (1781-1785); święcenia kapłańskie przyjął z rąk biskupa inflanckiego Józefa Kossakowskiego (1787); kustosz koadiutor 
łów, duchowieństwo oraz potrzeby powierzonych sobie wiernych, rozpoczął odwiedziny od parafii położonych w dekanatach: Brześć, Kobryń i Prużana. Zostały one przyłączone do diecezji wileńskiej z diecezji łuckiej po reorganizacji granic Kościoła łacińskiego dokonanej przez cara Pawła I ukazem z 8 maja 1798 r., zatwierdzonym przez papieża Piusa VI w dniu 15 października tego roku ${ }^{10}$.

Ordynariusz opuścił Wilno na początku sierpnia $1799 \mathrm{r}$. Kierował się w stronę Grodna, odwiedzając wybrane parafie. W dniu 11 września dotarł do Brześcia. Tam złożył wizytę m.in. w klasztorach dominikanów i trynitarzy ${ }^{11}$. Do Kobrynia przybył przed 16 września. Wizytację dekanatu kobryńskiego rozpoczął od jego siedziby - parafii pw. Wniebowzięcia NMP w Kobryniu, na terytorium której funkcjonowało probostwo szpitalne. Biskup najpierw zapoznał się ze stanem świątyni parafialnej i sprawdził inwentarze oraz dokumenty funduszowe zdeponowane w archiwum parafialnym. Później obejrzał plebanię, szpital i szkółkę parafialną. Następnie udał się do kaplicy, zwanej altarią kobryńską, umiejscowionej za cmentarzem prawosławnym przy jednej z kobryńskich cerkwi ${ }^{12}$. Po zakończeniu czynności wizytacyjnych przy altarii biskup jeszcze tego samego dnia przechodząc ul. Rynkową w stronę kościoła farnego, skręcił w prawo do probostwa szpitalnego z kościołem pw. św. Hieronima ${ }^{13}$. Całość zespołu szpitalnego, wraz z cmentarzem przykościelnym, otoczona była wówczas drewnianym parkanem $\mathrm{z}$ jedną bramą podwójną i dwoma mniejszymi bramkami ${ }^{14}$.

katedry wileńskiej z prawem następstwa (1788); członek Komisji Edukacji Narodowej Wielkiego Księstwa Litewskiego (1793); biskup inflancki (1794-1798); biskup wileński (1798-1808); prezes Komisji Edukacyjnej Litewskiej (1797); prezes Komisji Szpitalnej (1797); prezes Towarzystwa Dobroczynności w Wilnie (1807); w okresie rządów w diecezji wileńskiej m.in. wizytował parafie, przeprowadził reformę konsystorza i seminarium diecezjalnego, dokończył przebudowę katedry, dbał o rozwój szkolnictwa, na własny koszt wydawał książki do nauki, opracował projekt urządzenia szkolnictwa na Litwie, był jednym z założycieli dużego szpitala św. Jerzego w Wilnie; zmarł w Baden pod Wiedniem i tam został pochowany. L. Żytkowicz, Kossakowski Jan Nepomucen, w: Polski Stownik Biograficzny, t. 14, red. E. Rostworowski, Wrocław-Warszawa-Kraków 19681969, s. 265-267.

${ }^{10}$ B. Kumor, Granice metropolii i diecezji polskich (968-1939), „Archiwa, Biblioteki i Muzea Kościelne", 20 (1970) s. 301.

${ }^{11}$ W. Przyałgowski, Żywoty biskupów wileńskich, t. 3, Petersburg 1860, s. 219.

${ }^{12}$ Litewskie Państwowe Archiwum Historyczne w Wilnie (Lietuvos Vlastybès Istorijos Archyvas) (dalej: LVIA), f. 694, ap. 1, b. 3570, k. 2-6a.

${ }^{13}$ Szpitale prepozyturalne (prepozytury szpitalne, probostwa szpitalne) na ziemiach polskich zaczęły powstawać pod koniec XIII wieku. Intensywny rozwój tych instytucji miał miejsce w XIV, XV i pierwszej połowie XVI wieku. Był związany ze wzrostem znaczenia mieszczan. Z tego powodu fundacje tego rodzaju powstawały niemal wyłącznie w ośrodkach miejskich. Prepozytury szpitalne w odróżnieniu od szpitali parafialnych pod względem prawnym stanowiły samodzielne beneficjum, na równi z innymi beneficjami kościelnymi. Posiadały własny kościół z proboszczem (prepozytem) oraz własne i trwałe podstawy materialne zagwarantowane w dokumencie fundacyjnym. S. Litak, Parafie w Rzeczypospolitej w XVI-XVIII wieku. Struktura, funkcje społeczno-religijne i edukacyjne, Lublin 2004, s. 331; M. Surdacki, Opieka społeczna w Polsce do końca XVIII wieku, Lublin 2015, s. 120-125.

${ }^{14}$ LVIA, f. 694, ap. 1, b. 3570, k. 6 a. 
Wizytacja prepozytury szpitalnej rozpoczęła się od sprawdzenia mieszkania proboszcza i przytułku dla ubogich, ulokowanych w jednym budynku. Do lokum plebana wchodziło się z sieni przez drzwi na prawo. Miał on do swojej dyspozycji nowe, trzyizbowe mieszkanie z garderobą (nazywaną też spiżarnią). Każde z pomieszczeń posiadało drewniane okna $\mathrm{z}$ okiennicami. Dwie izby ogrzewał piec kaflowy wzniesiony z białych kafli, trzecią kominek. We wszystkich trzech pomieszczeniach były podłogi i sufity wykonane $\mathrm{z}$ desek. W garderobie dodatkowo umieszczone były schody prowadzące - przez drewniane drzwiczki - na strych ${ }^{15}$. Z pierwszej sieni przez przepierzenie przechodziło się do drugiej sieni (tzw. sień szpitalna), a z niej przez drzwi na lewo do pomieszczeń szpitala. Przytułek składał się z jednej dużej izby ogrzewanej piecem, dwóch małych sypialni (alkierzyków), niewielkiej kuchenki i czterech komórek z przepierzeniami ${ }^{16}$. W izbie głównej znajdował się piec ,izdebny” oraz piec chlebowy z kominem, trzy drewniane okna z szybami i okiennicami, podłoga gliniana i sufit drewniany. W sypialniach zaś dwa małe okna z szybami, bez okiennic. Każde pomieszczenie zamykano drzwiami drewnianymi na zawiasach, z klamkami i zaszczepkami. W kuchence był mały piec ,z chrustu i gliną olepiony”. Całość przykrywał nowy dwuspadowy dach $\mathrm{z}$ dranic ${ }^{17}$.

W dalszej kolejności wizytator przeszedł przez cmentarz przykościelny i wychodząc za wspomniane ogrodzenie, dotarł do oficyny będącej dawnym mieszkaniem proboszcza (stare probostwo). W skład budynku wchodziły: ganek, sień, duża izba, sypialnia (alkierz), spiżarnia, skład na naczynia, piwnica, kuchnia z piecem chlebowym. W głównej izbie stał piec kaflowy z zielonych kafli i komin z cegieł. Pomieszczenie posiadało cztery okna z szybami i okiennicami oraz podłogę i sufit $z$ desek. Przez wybudowane w spiżarni schody schodziło się do piwnicy ze ścianami z kamienia, na których wzniesiono spichlerz. Z pomieszczenia, gdzie składowano sprzęty i naczynia, wychodziło się na dziedziniec, przy którym stał chlewik. Mimo przeprowadzanych wcześniej prac remontowych budynek pozostawał w złym stanie technicznym, ,w częściach jednak stary zupełnie i spróchniały". Wiele do życzenia pozostawiał również dach budynku, wprawdzie kryty gontem, ale przegnitym i dziurawym. Ponadto dom zupełnie pozbawiony był wy-

${ }^{15}$ Tamże, k. 6a-6v.

${ }^{16}$ Zdecydowana większość szpitali funkcjonujących w omawianym okresie na ziemiach dawnej Rzeczypospolitej była budynkami drewnianymi, mieszczącymi od jednej do czterech izb wyposażonych w piece do ogrzewania (ewentualnie piec chlebowy), kilka komórek (służących jako sypialnie), spiżarnię i sień. Zob. np. K. Błażewicz, Szpitale diecezji płockiej w XVIII wieku, „Notatki Płockie", 47 (2002) nr 2 (191), s. 9; Z. Góralski, Szpitale na Lubelszczyźnie w okresie przedrozbiorowym, Warszawa-Łódź 1982, s. 36-37; K. Górska, Rozwój szpitalnictwa i opieki społecznej w dekanacie wegrowskim w XVII i XVIII wieku, „Radzyński Rocznik Humanistyczny”, 16 (2018) nr 1, s. 17-18; M. Hałaburda, Szpitale diecezji żmudzkiej na początku XIX stulecia, „Medycyna Nowożytna. Studia nad Kulturą Medyczną", 24 (2018) z. 2, s. 119-120; W. Partyka, Szpitale w diecezji wileńskiej w drugiej połowie XVIII wieku, w: Religie, edukacja, kultura, red. M. Surdacki, Lublin 2002, s. 627-629; J. Szczepaniak, Szpitale diecezji kamienieckiej około 1830 roku, „Textus et Studia”, 3 (2017) nr 11, s. 50; A. Woźniak, Szpitale wiejskie na Mazowszu w końcu XVIII wieku i początkach XIX wieku, w: Szpitalnictwo w dawnej Polsce, red. M. Dąbrowska, J. Kruppè, Warszawa 1998, s. 79.

${ }^{17}$ LVIA, f. 694, ap. 1, b. 3570, k. 6v. 
posażenia. Jak zanotował biskup, wszystkie meble i sprzęty gospodarskie zostały zagrabione przez wojska rosyjskie. Naprawy wymagał także spróchniały chlewik ${ }^{18}$.

W dość dobrym stanie pozostawał za to wspomniany spichlerz wzniesiony nad piwnicą. Był to budynek drewniany, zamykany drzwiami na zawiasach z żelazną zasuwką, a także z drewnianą podłogą i sufitem, kryty dranicami. Obok niego stała wybudowana z drewnianych dyli nowa szopka oraz stajnia (po środku) z wozownią (po lewej stronie) i spichlerzem (po prawej stronie) ${ }^{19}$. Przy oficynie, czyli dawnym probostwie, przechodząc za stajnie, miejsce zajmował ogród zasiany warzywami, ogrodzony częściowo parkanem drewnianym, a częściowo płotem, również drewnianym, i ostrokołem. Drugi ogród warzywny znajdujący się przy nowym domu szpitalnym, ogrodzony płotem drewnianym, wychodził swym zasięgiem poza rynek miejski. Obok nowego probostwa uprawiano jeszcze jeden, znacznie mniejszy, ogródek, obsiany drzewkami i kwiatami. Był on otoczony od strony ul. Rynkowej płotem, od strony zaś cmentarza drewnianym parkanem ${ }^{20}$.

Z ogrodów wizytator udał się do kościoła szpitalnego pw. św. Hieronima. Świątynia znajdowała się nieopodal rynku miejskiego. Był to budynek zbudowany z drewna, ,stary, dawny, nadpróchniały”, z kaplicą obitą deskami (tarcicami), zakrystią i chórem, zwieńczony niewielką kopułą. Całość nakrywał dach pokryty gontem. Do środka prowadziło wejście przez kruchtę (wystawę kościelną) zamykaną drzwiami na biegunach z dwoma „kunami” i dwoma żelaznymi zasuwami. Kolejne drzwi drewniane na zawiasach oraz z dwoma kunami i zasuwami oddzielały kruchtę od jednoprzestrzennego korpusu nawowego ${ }^{21}$. Wnętrze oświetlały cztery podwójne okna z szybami oprawionymi w ołów i dwa okna okrągłe, również z szybami oprawionymi w ten sam sposób. Ołtarz główny architektoniczny, rzeźbiony (snycerskiej roboty) dedykowany był patronowi świątyni. W nim znajdował się relikwiarz, trzy obrazy olejne za szkłem, trzy blachy z pobielonymi lichtarzami, dwie drewniane rzeźby oraz na ścianach cztery obrazy. Po obu stronach wisiało dziewięć obrazów, nad wejściem do zakrystii jeden i nad amboną jeszcze jeden wielki obraz wraz z dziesięcioma relikwiarzami. Obok znajdowała się prosta, drewniana ambona, do której prowadziły schody. Na niej zawieszone były dwa obrazy małe, jeden obraz gipsowy, dwa obrazy tkane na dywanie, trzy obrazy na płótnie i papierze. Przy ołtarzu stały także dwa żelazne świeczniki (lichtarze śrubowane), krzyż z drzewa hebanowego z mosiężnym korpusem pozłacany i cztery dzbanki na kwiaty ${ }^{22}$.

Na prawo od głównego ołtarza stał, snycerowany w gatunkowym drewnie, ołtarz św. Jana Nepomucena z zasuwą. Na zasuwie głównego obrazu namalowany był obraz przedstawiający Przemienienie Pańskie. Przy ołtarzu znajdował się je-

${ }_{18}$ Tamże, k. 6v-7.

19 Tamże k. 7v.

${ }^{20}$ Tamże.

${ }^{21}$ Z opisu wynika, że był to kościół salowy, czyli jednonawowy z prezbiterium i nawą takiej samej szerokości i wysokości ze wspólnym przykryciem, o jednolitym wnętrzu, sprawiającym wrażenie sali. Zob. Słownik terminologiczny sztuk pięknych, red. K. Kubalska-Sulkiewicz, M. Bielska-Łach, A. Manteuffel-Szarota, Warszawa 2016, s. 370.

${ }^{22}$ LVIA, f. 694, ap. 1, b. 3570, k. 7v-8v. 
den relikwiarzi jeden krzyżyk mosiężny. Na ścianie wisiał obraz Matki Bożej z dwoma srebrnymi koronami i sercami, a także nieco niżej obraz św. Kazimierza. Jako drugi wymieniono ołtarz św. Tekli. Usytuowany również po prawej stronie. Podobnie jak pierwszy, także wykonany według „,snycerskiej roboty”, posiadał zasuwę, na której widniał wizerunek św. Barbary. Na nim wisiał jeden krzyżyk i jeden relikwiarz ${ }^{23}$.

W prawym boku, idąc od strony głównego ołtarza, przylegała kaplica pw. Matki Bożej Miłosiernej. Wchodziło się do niej przez podwójne drzwi drewniane osadzone na zawiasach i krukach z żelazną zaszczepką. Oświetlenie kaplicy zapewniało sześć małych okratowanych okien: cztery kwadratowe i dwa okrągłe. Przy wejściu do kaplicy były umieszone: portrety - 4, relikwiarzyk - 1, obrazków małych - 2, obraz Pana Jezusa - 1. W kaplicy znajdował się ołtarz Matki Bożej Nieustającej Pomocy, „stary, obiciem papierowym okryty”. W jego centralnym miejscu widniał zasuwany obraz Matki Bożej Nieustającej Pomocy ze srebrną sukienką. Na zasuwie zajmował miejsce obraz z wizerunkiem św. Teresy. Na ołtarzu w kaplicy odnotowano także srebrne wotum, obrazek na srebrnej blasze w ramkach wykonanych z drewna hebanowego, srebrny relikwiarz, dwa pozłacane medaliki, korale „staroświeckie” z muszlami w perłach, srebrny krzyżyk na piersi, dwie perły, dwie obrączki, osiem wielkich cynowych lichtarzy, cztery mniejsze cynowe lichtarze, dwa mosiężne i dwa szklane lichtarze, trzy lichtarze drewniane malowane oraz jedną blaszaną i jedną drewnianą skarbonkę ${ }^{24}$. Wspomniano również o chórze wyposażonym jedynie w mały „pozytywek”25.

W kościele stał jeden konfesjonał, pięć ławek i jedna ławka mała. Ponadto do wyposażenie wnętrza zaliczono lampę blaszaną, mosiężny trybularz, sygnaturkę, krzyż, trzy małe dzwonki, i dwa dzwonki zamocowane na ścianach ${ }^{26}$.

Drobiazgowo zinwentaryzowano wyposażenie zakrystii. Składało się on z następujących przedmiotów: obrazy małe -4 , obrazy większe -3 , obrazy papierowe -4 , oratorium -1 , stolik drewniany -1 , krzesło -1 , stół z szufladą -1 , szafa 1 , baldachim -1 , velum -1 , birety sukienne -2 , srebrne kielich $\mathrm{z}$ patenami pozłacanymi -2 , puszka srebrna pozłacana -1 , mała puszka do chorych -1 , sukienek do krycia puszki -2 , agenda -1 , ewangelia -1 , kropidło drewniane -1 , kanonów do wszystkich ołtarzy $-12^{27}$. Dalej wyszczególniono bieliznę, paramenty liturgiczne i szaty ${ }^{28}$. W zamieszczonym poniżej zestawieniu tabelarycznym przedstawiono ich liczbę.

\footnotetext{
${ }^{23}$ Tamże, k. 8v.

${ }^{24}$ Tamże, k. 8, 9.

${ }^{25}$ Tamże k. $8 \mathrm{v}$.

${ }^{26}$ Tamże.

${ }^{27}$ Tamże k. 9.
}

${ }^{28} \mathrm{~W}$ pierwszej połowie XVIII wieku prepozytura szpitalna w Kobryniu była znacznie lepiej wyposażona w różnego rodzaju aparaty i sprzęty liturgiczne. Inwentarz sporządzony w $1738 \mathrm{r}$. wymienia następujące kategorie: (1) srebra (kielichy, krzyże, tabliczki, pateny, medaliki, lichtarze, dzwonki, obrączki, wisiorki itd.) - 42 pozycje, (2) ornaty - 7 pozycji, (3) kapy - 1 pozycja, (4) antependia - 5 pozycji, (5) zasłonki - 3, (6) vela - 5 pozycji; (7) bursy - 4 pozycje, (8) palki - 9 pozycji, (9) korporały - 4 pozycje, (10) alby - 12 pozycji. Zob. ADS, sygn. D 132, k. 192-193v. 
Tabela 1. Paramenty liturgiczne i szaty pozostające na wyposażeniu prepozytury szpitalnej pw. św. Hieronima w Kobryniu (1799 r.)

\begin{tabular}{|c|c|c|}
\hline Lp. & Pozycja & $\begin{array}{c}\text { Liczba } \\
\text { sztuk }\end{array}$ \\
\hline 1 & 2 & 3 \\
\hline 1. & Tuwalnie & 30 \\
\hline 2. & Alby (nowa) & 1 \\
\hline 3. & Alby (stare) & 3 \\
\hline 4. & Komże & 5 \\
\hline 5. & Ręczniki (większe) & 5 \\
\hline 6. & Ręczniki (mniejsze) & 4 \\
\hline 7. & Paski & 3 \\
\hline 8. & Humerały & 1 \\
\hline 9. & Mszały & 4 \\
\hline 10. & Mszał requialny & 1 \\
\hline 11. & Ornaty białe (nowe) & 12 \\
\hline 12. & $\begin{array}{l}\text { Ornat biały wyszywany w kwiaty srebrne i złote z kolumną złotem } \\
\text { haftowaną z galonem }\end{array}$ & 1 \\
\hline 13. & Ornat biały z kolumną w paski niebieskie z galonem srebrnym & 1 \\
\hline 14. & Ornat biały peruwianowy bez odmiany galonem srebrnym obszyty & 1 \\
\hline 15. & Ornat biały z lamy złotej z kolumną w kwiaty z galonem białym & 1 \\
\hline 16. & Ornat czerwony adamaszkowy z białymi bokami i galonem złotym & 1 \\
\hline 17. & Ornat czerwony w kwiaty srebrne z kolumną w paski niebieskie z kwiatami & 1 \\
\hline 18. & Ornat popielaty z kolumną czerwoną i złotym galonem & 1 \\
\hline 19. & Ornat fioletowy z gredyturu ${ }^{\mathrm{b}} \mathrm{z}$ kolumną peruwianową i złotym galonem & 1 \\
\hline 20. & Ornat czerwony drojetowy z kolumną wężową z białym galonem & 1 \\
\hline 21. & Ornat czarny z kolumną aksamitną czerwoną i białym galonem & 1 \\
\hline
\end{tabular}

${ }^{a}$ Peruwian (perubian) - odznaczająca się połyskiem, rzadka, dwuosnowowa tkanina jedwabna, o różnych barwach osnowy i wątku, wyrabiana z najgorszych gatunków przędzy. Wytwarzana we Francji w XVIII wieku, z przeznaczeniem na eksport głównie do Peru i również m.in. do Polski. I. Turnau, Stownik ubiorów. Tkaniny, wyroby pozatkackie, skóry, broń i klejnoty oraz barwy znane w Polsce od średniowiecza do poczatku XIX w., Warszawa 1999, s. 137.

${ }^{\mathrm{b}}$ Grodetur (gradytur, gredytur) - tkanina jedwabna, kolorowa, czasem wzorzysta, o średniej grubości, używana jako tkanina odzieżowa i tło do haftów. Sprowadzana głównie z Francji w drugiej połowie XVIII wieku, wytwarzana także w manufakturze grodzieńskiej. Tamże, s. 65. 


\begin{tabular}{|c|c|c|}
\hline 1 & 2 & 3 \\
\hline 22. & Ornat czarny z gęsiej skórki z kolumną białą w obtoki & 1 \\
\hline 23. & Manipularz, stuła, velum fioletowe & 1 \\
\hline 24. & Manipularze, stuły, velum czerwone & 2 \\
\hline 25. & Manipularze, stuły, velum białe & 5 \\
\hline 26. & Manipularze, stuły, velum czarne z palkami & 3 \\
\hline 27. & Korporały & 14 \\
\hline 28. & Puryfikaterze & 20 \\
\hline 29. & Stuły luźne & 5 \\
\hline 30. & Manipularze & 3 \\
\hline 31. & Patki & 9 \\
\hline 32. & Velumy & 6 \\
\hline 33. & Firanki & 5 \\
\hline 34. & Antependia & 2 \\
\hline 35. & Dywany & 4 \\
\hline 36. & Nakrywki do ołtarzy & 4 \\
\hline 37. & Ampułki & 4 \\
\hline 38. & Kociołek do wody & 1 \\
\hline 39. & Kropielniczka cynowa & 1 \\
\hline 40. & Lamy $^{\mathrm{c}}$ & 7 \\
\hline
\end{tabular}

Źródło: LVIA, f. 694, ap. 1, b. 3570, k. 9-9v.

Protokół powizytacyjny wyraźnie określił obowiązki ciążące na proboszczu probostwa szpitalnego i jego następców. Należało do nich odprawienie: (1) w każdym tygodniu przez cały rok jednej mszy czytanej za żywych i zmarłych fundatorów kościoła (łącznie w roku 52 msze); (2) w każdym tygodniu przez cały rok jednej mszy czytanej za duszę ks. Kazimierza Szpotańskiego i dusze w czyśćcu cierpiące (rocznie $52 \mathrm{msze}$ ); (3) raz w miesiącu mszy czytanej w intencji Rafała i Krystyny Massalskich (w roku 12 mszy); (4) raz w miesiącu mszy czytanej za duszę Andrzej Bojarskiego i jego krewnych (w roku 12 mszy); (5) dwie msze

${ }^{\mathrm{c}}$ Lama - zwrot używany dawniej na określenie złotej lub srebrnej blaszki do pasów. Ewentualnie tkanina jedwabna o tle całkowicie lub częściowo pokrytym dodatkowymi wątkami: złotym, srebrnym lub metalowym, bardzo często występująca w postaci folii. Tamże, s. 103; I. Żuraszek-Ryś, Nazwy tkanin wschodniego pochodzenia w osiemnastowiecznej polszczyźnie (na przykładzie materiału z dwóch inwentarzy skarbca archikatedralnego kościoła ormiańskiego we Lwowie, „Zielonogórskie Seminaria Językoznawcze”, (2016) s. 141. 
w miesiącu przez 1796 r. za duszę ks. Andrzeja ${ }^{29}$ od dnia rocznicy śmierci przypadającej 29 stycznia (w roku 24 msze); (6) mszy za dusze Stanisława i Aleksandry Kuleszów (jedna msza w roku); (7) mszy za duszę Jana Kracewicza (10 mszy w roku). Łącznie każdego roku proboszcz szpitalny zobowiązany był do odprawienia 163 mszy funduszowych ${ }^{30}$.

Obok kościoła nad ul. Rynkową znajdowała się drewniana dzwonnica zbudowana z drewna, stojąca na czterech słupach, oszalowana drewnianymi deskami. Na niej podwieszone były dwa „miernej wielkości” dzwony ${ }^{31}$.

Wizytator miał również obowiązek sprawdzenia stanu należących do probostwa szpitalnego zabudowań folwarcznych. Usytuowane były one za miastem i prowadziła do nich ul. Garbarska. W opracowaniu pominięto jednak opisy tych zabudowań ze względu na ich szczegółowość. Wymieniono jedynie budynki, które wchodziły w skład gospodarstwa: (1) budynek drewniany, potrzebujący remontu, z sienią, mieszkaniem gospodarskim (po lewej stronie), piekarnią (po prawej stronie); (2) stajnia nowa, wzniesiona $\mathrm{z}$ drewna, na rzucie kwadratu $\mathrm{z}$ trzema chlewami; (3) dwa chlewki dostawione do stajni; (4) stodoła, nowa z bali, stojąca na słupach dębowych, wybudowana w 1797 r., ze spichlerzem i wozownią; (5) szopa „,z chrustu upleciona”. Wszystkie zabudowania folwarczne pokryte były strzechą. $\mathrm{Na}$ środku dziedzińca znajdowała się studnia, jak zanotował wizytator, ,reparacji potrzebująca". Całość otaczało ogrodzenie częściowo wykonane z żerdzi drewnianych, a od ul. Garbarskiej z ostrokołu ${ }^{32}$.

W dalszej relacji wizytator wymienił ogrody, grunty, plony i wpływy pieniężne będące własnością probostwa. Do folwarku należały dwa ogrody warzywne położone za miastem ponad rzeką Muchawiec. Ponadto własnością majątku były grunty w dokumencie nazywane polami: za wsią Gubernia Kobryńska ${ }^{33}$, we wsi Zaprudy $^{34}$, za rzeką Litewką, pod wsią Lepiosy ${ }^{35}$, nad rzeką Muchawiec. Każdego roku w gospodarstwie wysiewało się ok. 23 szanków $^{36}$ i 2 garnce ${ }^{37}$ różnego rodzaju zbóż i roślin uprawnych. W roku wizytacji na taki wynik złożyły się wysiewy: żyta (12 szanków), pszenicy (1 szanek), jęczmienia (4 szanki), owsa (4 szanki),

${ }^{29}$ Chodzi o ks. Andrzeja Gurskiego, byłego proboszcza kościoła św. Hieronima, zmarłego w 1796 r. Zob. LVIA, f. 694, ap. 1, b. 3782, k. 231, 234v.

${ }^{30}$ LVIA, f. 694, ap. 1, b. 3570, k. 8.

${ }^{31}$ Tamże, k. 9.

${ }^{32}$ Tamże, k. 9v-10v.

${ }^{33}$ Gubernia (biał. Губерня) - dawniej folwark położony ok. $1 \mathrm{~km}$ na południowy wschód od Kobrynia; obecnie w granicach miasta Kobryń.

${ }^{34}$ Zaprudy (biał. Запруды) - wieś w rejonie Kobryń i sielsowiecie Ostromecz, położona ok. $20 \mathrm{~km}$ na północny wschód od Kobrynia.

${ }^{35}$ Leopisy (biał. Лепясы) - dawniej folwark położony na północny wchód od Kobrynia w odległości ok. 2,5 km; obecnie w granicach miasta Kobryń.

${ }^{36}$ Szanek - dawna miara objętości zboża zawierająca 24 lub 48 garnców (ok. 100 lub 200 litrów). Zob. Słownik języka polskiego, red. W. Doroszewski, t. 8, Warszawa 1966, s. 1015.

${ }^{37}$ Garniec staropolski - dawna miara objętości ciał sypkich zawierająca 4 kwarty (1 kwarta 0,94 litra). Zob. S.B. Linde, Stownik języka polskiego, t. 1, cz. 2: G-L, Warszawa 1808, s. 684; I. Ihnatowicz, A. Biernat, Vademecum do badań nad historia XIX i XX wieku, Warszawa 2003, s. 48. 
grochu (1 szanek), gryki (1 szanek), prosa (2 garnce) ${ }^{38}$. Oprócz tego fundusz probostwa szpitalnego zasilały środki z dzierżawy budynków i sum funduszowych lokowanych na procent. Zanotowano tutaj: opłatę za dzierżawę karczmy przez Skarb Imperatorski, wypłacaną z kasy kobryńskiej - 500 złotych, przychody z dóbr hrabiego Aleksandra Suworowa ${ }^{39}-300$ złotych, kapitał od sumy lokowanej na procent - 427 złotych. W sumie probostwo szpitalne mogło liczyć na 1227 złotych rocznego przychodu ${ }^{40}$.

O zapleczu materialnym probostwa precyzyjnych informacji dostarcza również „Rejestr dokumentów funduszowych” opisany w aktach wizytacji jako ostatni punkt protokołu przed dekretem reformacyjnym. Zestawienie, zapisane na czterech kartach (osiem stron), podzielone zostało na jedenaście fascykułów. W poszczególnych fascykułach, oznaczonych literami („AAA”, „BBB”, „CCC”, „DDD”, „EEE”, „FFF”, „GGG”, „HHH”, „III”, „KKK”, „LLL”), uporządkowano dokumenty funduszowe według ich rangi. Stopień szczegółowości i obszerność zapisów nie pozwalają na przytoczenie w niniejszym opracowaniu rejestru w całości. Wymieniono jedynie dokumenty najważniejsze, wyszczególnione w fascykule oznaczonym samogłoskami „AAA”. Odnotowano tutaj trzy pozycje. Pierwsza to księga oprawiona w skórę, w której znajdowały się zapisy potwierdzające odnowienie fundacji z 16 września 1624 r. przez Hieronima (Jarosza) Wołłowicza, starostę generalnego żmudzkiego, wraz z kopiami dalszych dokumentów funduszowych oraz protokołami wizytacji kościoła przeprowadzonej przez ks. Wincentego Sucheckiego w dniu 28 czerwca 1723 r. W drugiej zanotowano przywileje królewskie potwierdzające odnowienie fundacji przez starostę generalnego żmudzkiego. Dokumentów tego rodzaju rejestr wymienia razem siedem, bez opisu każdego z osobna. Wszystkie pisane były na pergaminie i zaopatrzone pieczęciami woskowymi zamkniętymi w puszkach. W ostatniej pozycji z tego fascykułu wymieniono dokument stanowiący zatwierdzenie (konfirmację) fundacji Hieronima (Jarosza) Wołłowicza przez królową Konstancję, małżonkę króla Zygmunta III Wazy. Aktu tego dokonano na zamku w Warszawie 19 marca 1625 r. Treść spisano na papierze. Według opisu wizytatora dokument już wówczas był podarty i zwinięty w arkusz ${ }^{41}$.

${ }^{38}$ LVIA, f. 694, ap.1, b. 3570, k. 10v-11.

${ }^{39}$ Suworow Aleksandr Wasiljewicz (ros. Суворов Александр Васильевич) (1729-1800) książę Sardynii i hrabia Rymnika (od 1789 r.), książę Italii (od 1799 r.), generał major (od 1774 r.), feldmarszałek (od 1794 r.), generalissimus (od 1799 r); rosyjski dowódca, jeden z twórców rosyjskiej teorii militarnej; kawaler licznych orderów i wyróżnień; uczestnik i zwycięzca wielu kampanii militarnych; w randze pułkownika brał udział w tłumieniu konfederacji barskiej; głównodowodzący wojsk rosyjskich podczas insurekcji kościuszkowskiej; szturmem zdobył warszawską Pragę, dokonując rzezi ludności cywilnej „rzezi Pragi”; dowódca okupacyjnych wojsk rosyjskich w Polsce (1794-1796), w nagrodę za poskromienie Warszawy otrzymał od Katarzyny II w dniu 18 (29) sierpnia 1795 r. „Klucz kobryński” wraz z siedmioma tysiącami dusz. С. Масловский, Суворов Александр Васильевич, в: Русский биографический словарь, т. 20, Санкт-Петербург 1912, с. 7-79.

${ }^{40}$ LVIA, f. 694, ap.1, b. 3570, k. 11.

${ }^{41}$ Tamże 11-11v. 
Pozostałe części rejestru dokumentów funduszowych liczyły kolejno: fascykuł „BBB” - 9 pozycji (dokumentów - 14), fascykuł „CCC” - 1 (dokumentów - 6), fascykuł „DDD” - 16 (dokumentów - 24), fascykuł „EEE” - 1 (dokumentów kilkanaście), fascykuł „FFF” - 1 (dokumentów - 11), fascykuł „GGG” - 1 (dokumentów 10), fascykuł „HHH”- 1 (dokumentów - 8), fascykuł „III” - 1 (dokumentów 20), fascykuł „KKK”-1, (dokumentów 10), fascykuł „LLL”- 3 (dokumentów 28). Trzeba w tym miejscu jeszcze tylko dodać, że na podstawie zestawienia można odtworzyć kapitały lokowane na procent na miejscowych dobrach ziemskich oraz grunty, place i łąki legowane dawniej przez mieszczan na fundusz szpitalny. Materiały w takiej postaci mogą stać się podstawą odrębnego opracowania. Łatwo też zauważyć, że dokumenty potwierdzające prawa do zapisów pieniężnych oraz nieruchomości pozostających własnością probostwa szpitalnego były uporządkowane i przechowywane przez proboszczów z największą starannością ${ }^{42}$.

Protokół powizytacyjny nie wspomina nic o ubogich szpitala kobryńskiego. Brak jest informacji na temat ich liczby, płci, wieku, liczby lat przebywania w przytułku. Nie wiadomo również nic o ich codziennych zajęciach i obowiązkach. Podobnie brakuje wiadomości poświęconych urzędującemu proboszczowi. Wiadomo tylko, że urząd ten w okresie wizytacji pełnił ks. Werner Kwiatkowski, kanonik inflancki ${ }^{43}$. Mimo tych mankamentów lustracja dostarcza prawie całościowy obraz funkcjonowania instytucji charytatywno-społecznej. Pozwala odtworzyć wygląd kompleksu zabudowań probostwa szpitalnego, a także uchwycić stan ich zachowania.

Analizując zebrane informacje, należy stwierdzić, że u schyłku XVIII wieku probostwo szpitalne w Kobryniu pozostawało w dobrej kondycji. Odpowiednio uposażone i dobrze zarządzane wypełniało w sposób odpowiedni misję, do jakiej zostało powołane przez fundatorów. Otaczając opieką najbardziej potrzebujących mieszkańców miasta, dobrze wpisywało się w działalność charytatywną Kościoła. Takiego stanu rzeczy nie mogły zmienić zauważone w czasie wizytacji uchybienia, czyli część zabudowań potrzebujących napraw i remontów. Wydaje się, że nie stanowiły one palącego problemu. W zarządzeniach powizytacyjnych sformułowanych w dekrecie reformacyjnym wizytator zapisał:

Chociaż uznaliśmy, że wielce czcigodny ksiądz Werner Kwiatkowski, kanonik inflancki, prezpozyt szpitalny kościoła w Kobryniu słusznie będzie nadal pełnił swój urząd, to jednak, aby miał świadectwo naszej wizytacji, pasterskiej troski i życzliwości, zachęcamy go w Panu, aby troska, którą z miłości ku ubogim Chrystusa już ich otacza, stała się jego szczególnym obowiązkiem i zechciał im nadal służyć i ich wspierać. Nie wątpimy, że tą samą miłością

${ }^{42}$ Tamże k. 11-14

${ }^{43}$ Kwiatkowski Werner (1738-1802) - kanonik inflancki (liwoński), altarzysta olszewski, prepozyt kościoła szpitalnego pw. św. Hieronima w Kobryniu (1796-1800); zrezygnował z zajmowanej funkcji (1800). LVIA, f. 694, o. 1, d. 3782, k. 234v; Directorium horarum canonicarum et missarum pro diaecesi vilnensi in annum Domini 1803, Vilnae 1803, (nlb.). 
pobudzany tak jak teraz, tak i w przyszłości, będzie przychodził z pomocą ich potrzebom, tak doczesnym, jak i duchowym, według zamysłu fundacji, równocześnie troszcząc się o kościół i budynki ${ }^{44}$.

Wizytator opuścił miasto i udał się do oddalonego o ok. $32 \mathrm{~km}$ Olizarowego Stawu. Dojechał tam 18 września i przeprowadził oględziny tamtejszego kościoła parafialnego. Kolejnymi miejscami jego przejazdu były pozostałe parafie należące do dekanatu Kobryń: Dywin, Horodec, Drohiczyn, Janów, Zbirogi, Bezdzież, Krupczyce i Buchowicze. W dalszym ciągu swojej podróży odwiedził kościoły parafialne i klasztorne w dekanacie prużańskim: Prużana, Kiwatycze, Siehnieiwcze, Szereszów, Bereza Kartuska, Sielec i Narewka. W ostatniej z wymienionych parafii biskup przebywał do 3 października. Tam też zakończył objazd wizytacyjny. Z Narewki, już prawdopodobnie następnego dnia, ruszył w drogę powrotną do Wilna $^{45}$. Odpoczynek biskupa nie trwał długo, gdyż niebawem rozpoczął podróż do Rzymu, by wziąć udział w uroczystościach pogrzebowych papieża Piusa VI ${ }^{46}$.

Pod koniec lipca 1800 r. ks. Werner Kwiatkowski złożył rezygnację z urzędu prepozyta kościoła szpitalnego. Jego miejsce zajął ks. Piotr Rudnicki ${ }^{47}$. W roku następnym (1801) kościół pw. św. Hieronima przestał istnieć. W wyniku pożaru budynek wraz z większością wyposażenia i archiwaliów uległ całkowitemu zniszczeniu. Mimo planów nigdy nie udało się go odbudować ${ }^{48}$. Część sprzętów ocalałych z pożogi przeniesiono do kościoła pw. Wniebowzięcia NMP. Niestety one również zostały utracone bezpowrotnie, kiedy świątynia parafialna spłonęła w czasie działań wojennych 1812 r. ${ }^{49}$ Ogień nie oszczędził także zabudowań szpital-

${ }^{44}, P[e] r[i] l[l$ lustr] $e m$ Ad[modu]m R[evere]ndum Vernerium Kwaitkowski, Canonicum Livoniensem, Praepositum hospitalis Ecclesiae Kobrynien[sis] licet munere suo rite functorum depraetiondimus, altamen ut visitationis nostrae et pastoralis solicitudinis ac benevolentiae, habeat documentum, hortamar Eum inD[omi]no, ut charitate pauperes Christi, quorum cura ea praecellenti, quod gerit, munere specialiter ipsi incumbit, prosequi ac fovere velit. Nec dubitamus quin eadem Charitate stimulante, sicut nunc, ita in posterum etiam indigentiis eorum, tam temporalibus, quam spiritualibus ad mentem fundationis surcuret, unaque curam Ecclesiae et aedificorum habebit. In quorum fidem". LVIA, f. 694, ap. 1, b. 3570, k. 15v.

${ }^{45}$ Tamże, k. 163v, 164v; Przyałgowski, Żywoty biskupów, s. 220.

${ }^{46}$ Papież Pius VI zmarł 29 sierpnia 1799 r. w Valence we Francji jako więzień wojsk napoleońskich w tamtejszej cytadeli. Został pochowany na miejscowym cmentarzu dopiero po czterech miesiącach na polecenie Napoleona. W 1802 r. jego ciało przewieziono do bazyliki św. Piotra w Rzymie F.K. Seppelt, K. Löffler, Dzieje papieży od początków Kościoła do czasów dzisiejszych, Poznań 1936, s. 470; J.N.D. Kelly, Encyklopedia papieży, Warszawa 2006, s. 423; Przyałgowski, Żywoty biskupów, s. 220.

${ }^{47}$ LVIA, f. 694, ap. 1, b. 3782, s. 234v.

${ }^{48}$ Biskupstwo wileńskie, s. 235-236.

${ }^{49} \mathrm{~W}$ czasie inwazji Napoleona na Rosję, w dniu 15 (27) lipca 1812 r. pod Kobryniem rozegrała się bitwa, będąca pierwszym znaczącym zwycięstwem rosyjskim. Po bitwie wybuchł ogromy pożar, który strawił większą część miasta. Obok kościołów i cerkwi zniszczonych zostało 548 domów, ocalało zaś jedynie 82. Straty szacowano na 270 tys. rubli srebrnych. А.И. Михайловский-Даниловский, Описание Отечественной войны в 1812 году.ч. 1, Санкт-Петербург 1839, с. 370; Szerzej o bitwie zob. Н.П. Поликарпов, Боевой календарь-ежедневник Отечественной войнь 1812 года, т. 4, ч. 1, Москва 1913, с. 170-180. 
nych i dawnego probostwa szpitalnego (oficyna). W $1801 \mathrm{r}$. mieszkanie prepozyta oraz przytułek dla ubogich przeniesiono do zabudowań folwarku położonego za miastem. W $1818 \mathrm{r}$. rozpoczęto tam budowę nowego domu szpitalnego. Wówczas w szpitalu przebywało pięć osób ubogich i troje sierot. Sierotom obok schronienia dodatkowo zapewniano elementy opieki wychowawczo-edukacyjnej poprzez początkową naukę czytania ${ }^{50}$.

Z przeprowadzonej wizytacji w 1830 r. można uzyskać informację, że na miejscu, gdzie kiedyś stał kościół i budynek szpitala, od chwili pożaru w $1801 \mathrm{r}$. nie wykonano żadnych prac remontowo-budowlanych. Szpital mieścił się w nowym budynku wzniesionym w $1818 \mathrm{r}$. na terenie folwarku za miastem przy ul. Garbarskiej. Kuratelę nad nim sprawował proboszcz kościoła parafialnego w Kobryniu. W drugiej połowie XIX wieku w oficjalnych drukach kościelnych prepozytury szpitalnej już nie notowano. Kościoła, mimo że pozostawał pod patronatem biskupów wileńskich, nie odbudowano nigdy. Pod koniec XVIII wieku zmianie uległy koncepcje dobroczynności oraz podejście do opieki i samej roli szpitali. Kościelne szpitale specjalizujące się w opiece nad biednymi stopniowo zastępowały placówki, których główną funkcją było leczenie chorych. W ten sposób przestał istnieć także szpital przy folwarku ${ }^{51}$. Wraz z nim po blisko trzystu latach ostatecznie swoją misję zakończyła prepozytura szpitalna w Kobryniu, w potocznym obiegu równolegle funkcjonująca pod nazwą probostwa szpitalnego.

\section{REFERENCES / BIBLIOGRAFIA}

\section{Źródła rękopiśmienne}

Archiwum Diecezjalne w Siedlcach (ADS)

sygn. D 132, Acta Visttationis Ecclesiarum Parochialium Decanatus Branscensis et Szereszoviensis in Anno 1737.

sygn. D 155, Liber Visitationum Ecclesiarum Parochialium Dioecesis Luceoriensis et Brestensis ex fragmentis collectorum compositus in Anno 1831.

Litewskie Państwowe Archiwum Historyczne w Wilnie (Lietuvos Vlastybès Istorijos Archyvas) (LVIA)

f. 694, ap. 1, b. 3570, Opisanie Kościołów w Dekanatach Kobryńskim i Prużańskim w Czasie Wizyty Jeneralnej Dyecezyi przez JW. Jana Nepomucena Korwina Kossakowskiego, Biskupa Wileńskigo w Roku 1799 Odprawioney.

f. 694 , ap. 1, b. 3782, Księga wizytacji kościołów i klasztorów w dekanacie brzeskim i kobryńskim z $1830 \mathrm{r}$.

f. 694, ap. 1. b. 4015, Wizyty za rok 1818 kościołów i plebaniow dyecezii wileńskiej w guberni grodzienskiey sygnowanych.

${ }^{50}$ LVIA, f. 694, ap. 1. b. 4015, k. 266.

${ }^{51}$ M. Surdacki, Szpital świętego Ducha i św. Leonarda w Urzędowie w XV-XVIII wieku, „Kwartalnik Historyczny”, 112 (2004) z. 2, s. 8. 


\section{Źródła drukowane}

Directorium horarum canonicarum et missarum pro dioecesi vilnensi in annum Domini 1803, Vilnae 1803.

Linde Samuel Bogumił, Stownik języka polskiego, t. 1, cz. 2: G-L, Warszawa 1808.

Spis kościołów i duchowieństwa diecezji pińskiej w R.P. 1939, Pińsk 1939.

Michajłowskij-Daniłowskij Aleksandr Ivanovič, Opisanije otieczestwiennoj wojny w 1812 godu, cz. 1, Sankt-Pietierburg 1839.

\section{Opracowania}

Biskupstwo Wileńskie: od jego założenia do dni obecnych, zawierajace dzieje i prace biskupów i duchowieństwa diecezji wileńskiej, oraz wykaz kosciołów, klasztorów, szkół i zakładów dobroczynnych i społecznych, oprac. J. Kurczewski, Wilno 1912.

Błażewicz Krzysztof, Szpitale diecezji płockiej w XVIII wieku, „Notatki Płockie”, 47 (2002) nr 2 (191), s. 8-17.

Bobryk Adam, Dmowski Rafał, Odbudowa dziedzictwa kulturowego Kobrynia poprzez funkcjonowanie parafii katolickiej, w: Blisko, a tak daleko: Polacy w obwodzie brzeskim na Białorusi, red. A. Bobryk, Siedlce 2004, s. 195-200.

Čanturija Vladimir Aleksandrovič, Architiekturnyje pamiatniki Bielorussii, Minsk 1982.

Filipczak Witold, Ekonomie litewskie w polityce sejmikowej Stanisława Augusta po upadku Antoniego Tyzenhauza (1780-1783), „Przegląd Nauk Historycznych”, 5 (2006) nr 1 (9), s. 235-276.

Góralski Zbigniew, Szpitale na Lubelszczyźnie w okresie przedrozbiorowym, Warszawa-Łódź 1982.

Górska Krystyna, Rozwój szpitalnictwa i opieki społecznej $w$ dekanacie węgrowskim w XVII i XVIII wieku, „Radzyński Rocznik Humanistyczny”, 16 (2018) nr 1, s. 9-28.

Ihnatowicz Ireneusz, Biernat Andrzej, Vademecum do badań nad historia XIX i XX wieku, Warszawa 2003.

Kazloŭ Leŭ, Kobrynskaja ekanomija, w: Vialikaje Kniastva Litoŭskaje. Encyklapiedyja $\breve{u}$ 2-ch tamach, red. H.P. Paškoŭ, t. 2, Minsk 2007, s. 117.

Kelly John Norman Davidson, Encyklopedia papieży, Warszawa 2006.

Kulahin Anatoĺ Mikalajevič, Katalickiia chramy Bielarusi, Minsk 2008.

Kumor Bolesław, Granice metropolii i diecezji polskich (966-1939), „Archiwa, Biblioteki i Muzea Kościelne”, 20 (1970) s. 253-374.

Litak Stanisław, Atlas Kościoła łacińskiego w Rzeczypospolitej Obojga Narodów w XVIII wieku, Lublin 2006.

Litak S., Parafie w Rzeczypospolitej w XVI-XVIII wieku. Struktura, funkcje spoleczno-religijne i edukacyjne, Lublin 2004.

Marczak Michał, Przewodnik po Polesiu, Brześć nad Bugiem 1935.

Maslowskij Siergiej, Suworow Aleksandr Vasiljewicz, w: Russkij biografičeskij slowar', t. 20, Sankt-Peterburg 1912, s. 7-89.

Materiały do dziejów sztuki sakralnej na ziemiach wschodnich dawnej Rzeczypospolitej, cz. 5: Kościoły i klasztory rzymskokatolickie dawnego województwa brzeskolitewskiego, t. 1-4, red. J.K. Ostrowski, Kraków 2013-2019.

Partyka Wiesław, Szpitale w diecezji wileńskiej w drugiej połowie XVIII wieku, w: Religie, edukacja, kultura. Ksiega pamiątkowa dedykowana Profesorowi Stanistawowi Litakowi, red. M. Surdacki, Lublin 2002, s. 623-631.

Polikarpov Nikolaj Pietrovič, Bojewoj kalendar'-ježedniewnik Otiečestwiennoj wojny 1812 goda, t. 4, cz. 1, Moskva 1913. 
Przyałgowski Wincenty, Żywoty biskupów wileńskich, t. 3, Petersburg 1860.

Relihija i Cierkwa na Bielarusi. Encyklapiedyčny dawiednik, red. H.P. Paškoŭ, Minsk 2001.

Seppelt Franciszek Ksawery, Löffler Klemens, Dzieje papieży od początków Kościoła do czasów dzisiejszych, Poznań 1936.

Słownik geograficzny Królestwa Polskiego i Litwy i innych krajów słowiańskich, red. F. Sulimierski, t. 4, Warszawa 1883.

Słownik języka polskiego, red. W. Doroszewski, t. 8, Warszawa 1966.

Stownik terminologiczny sztuk pięknych, red. K. Kubalska-Sulkiewicz, M. Bielska-Łach, A. Manteuffel-Szarota, Warszawa 2016.

Surdacki Marian, Opieka społeczna w Polsce do końca XVIII wieku, Lublin 2015.

Surdacki Marian, Szpital świętego Ducha i św. Leonarda w Urzędowie w XV-XVIII wieku, „Kwartalnik Historyczny”, 112 (2004) z. 2, s. 5-35.

Svod pamiatnikov istorii i kul'tury Bielorussii. Brestskaja oblast', red. S.V. Marcelev, Minsk 1990, s. 243-252.

Szczepaniak Jan, Szpitale diecezji kamienieckiej około 1830 roku, „Textus et Studia”, 3 (2017) nr 11, s. 41-60.

Turnau Irena, Stownik ubiorów. Tkaniny, wyroby pozatkackie, skóry, broń i klejnoty oraz barwy znane w Polsce od średniowiecza do poczatku XIX w., Warszawa 1999.

Vialiki histaryčny Atlas Bielarusi ŭ 4-ch tamach, red. H.I. Kuzniacoŭ, t. 3, Minsk 2016.

Woźniak Andrzej, Szpitale wiejskie na Mazowszu w końcu XVIII wieku i początkach XIX wieku, w: Szpitalnictwo w dawnej Polsce, red. M. Dąbrowska, J. Kruppè, Warszawa 1998, s. 75-87.

Żuraszek-Ryś Iwona, Nazwy tkanin wschodniego pochodzenia w osiemnastowiecznej polszczyźnie (na przykładzie materiału z dwóch inwentarzy skarbca archikatedralnego kościoła ormiańskiego we Lwowie, „Zielonogórskie Seminaria Językoznawcze”, (2016) s. 137-147.

Żurek Waldemar Witold, Inwentarz rzymskokatolickiego kościoła parafialnego w Kobryniu z 21 sierpnia 1933 roku, „Archiwa, Biblioteki i Muzea Kościelne”, 109 (2018) s. 399-412.

Żytkowicz Leonid, Kossakowski Jan Nepomucen, w: Polski Słownik Biograficzny, t. 14, red. E. Rostworowski, Wrocław-Warszawa-Kraków 1968-1969, s. 265-267. 


\title{
ST. JEROME'S HOSPITAL PROVOSTRY IN KOBRYN FROM THE PERSPECTIVE OF THE VISITATION REPORT OF 1799
}

\begin{abstract}
The article presents the history of the St. Jerome's Hospital Parish in Kobryn, its condition and operation at the end of the 18th century. The text is based on the protocol of the general visitation carried out in 1799 by the bishop of Vilnius, Jan Nepomucen (Korwin) Kossakowski in the Kobryn and Pruzhany deaneries. The document is stored by the Lithuanian State Historical Archives in Vilnius (Lietuvos Vlastybès Istorijos Archyvas) (LVIA) under the reference number f. 694, ap. 1, b. 3570.
\end{abstract}

Keywords: bishop Jan Nepomucen (Korwin) Kossakowski; Kobryn deanery; Vilnius diocese; Kobryn; hospital provostry; hospital parish; general visitation 